\title{
Improved Learning of the Healthy Living Community Movement During the Pandemic for Budi Cendekia Islamic School Students
}

\author{
Erlina Puspitaloka Mahadewi ${ }^{1 *}$, Mohamad Reza Hilmy², \\ Intan Silviana Mustikawati ${ }^{3}$, Suryari Purnama ${ }^{4}$, Arman Harahap ${ }^{5}$ \\ ${ }^{1,2,3}$ Public Health Study Program, Faculty of Health Sciences, \\ Universitas Esa Unggul, Jakarta Indonesia. \\ ${ }^{4}$ Faculty of Economics and Business, Universitas Esa Unggul, Jakarta Indonesia. \\ ${ }^{5}$ Universitas Labuhanbatu, Sumatera Utara, Indonesia \\ ${ }^{*}$ Corresponding Author: \\ Email: erlina.puspitaloka@esaunggul.ac.id
}

\begin{abstract}
.
Changes in disease patterns in Indonesia are often referred to as the epidemiological transition. In the 1990s the biggest cause of death and illness was infectious diseases. However, in the era of the last 10 years from 2010 to 2020 the biggest causes and causes of death and illness are non-communicable diseases. The increased risk of non-communicable diseases is due to the demographic transition. The Healthy Living Community Movement or commonly known as GERMAS is a movement initiated by the President of the Republic of Indonesia that prioritizes promotive and preventive efforts without compromising curativerehabilitative efforts. This activity aims to raise public awareness, especially high school students, to be independent in doing GERMAS. Especially in disseminating information about the importance of implementing GERMAS during the Covid-19 pandemic. The activity is carried out using the seminar method, and was carried out by a team of 10 students, 1 lecturer and 1 health practitioner. The implementation time during this community service takes place which is 15 to 20 minutes for each topic with a presentation. After carrying out a series of activities, the committee provides an evaluation link that can be filled in by the participants. The results of the research show that the success rate is above $51 \%$ and shows that this community service will affect the target in carrying out GERMAS even though this activity is carried out virtually using the zoom meeting application. The activity in the next future needs to be improved again in the delivery of material and in answering the material in a language that is easily understood by high school students.
\end{abstract}

Keywords: budi cendekia islamic school, community service, covid-19, GERMAS, high school students.

\section{INTRODUCTION}

In the last 30 years, Indonesia has experienced a change in disease patterns which is often called the epidemiological transition. In the 1990s, the biggest causes of death and illness were infectious diseases such as upper respiratory tract infections (ARI), tuberculosis, diarrhea, and others. However, during the 2010 era, the biggest causes of death and illness were non-communicable diseases such as stroke, heart 
disease, and diabetes. And now non-communicable diseases do not only attack old age but also young people, both from rich and poor people, living in cities and villages like in case in Kulon Progo Health Office, 2020 [1].

Currently, Indonesia is facing a big challenge, namely the triple burden of health problems, because there are still infectious diseases, increasing noncommunicable diseases and other diseases that should have been resolved reappear. The increasing incidence of non-communicable diseases (PTM) such as stroke, coronary heart disease (CHD), cancer and diabetes is caused by changes in people's lifestyles. The increased risk of PTM is due to the demographic transition, namely the increasing proportion and number of adults and elderly people who are susceptible to PTM and degenerative diseases. This causes the need for long-term treatment and care where this can increase the burden of government health financing as well as increase the family's economic burden due to decreased family productivity, and not infrequently this causes families to fall into poverty because they take care of sick family members. Therefore, concerted efforts are needed to prevent these PTM risk factors. These efforts are in the form of prevention activities that involve all levels of Indonesian society regardless of age, type of work, social status, economic status, and location of residence [2]

The government has also developed a framework for implementing messages to strengthen the health development paradigm from curative and rehabilitative to promotive and preventive efforts carried out through a multi-sectoral approach, as well as formulating action plans related to strengthening health promotive and preventive efforts. it is also focused on the preparation of the Healthy Living Community Movement (GERMAS) which will be a guide for relevant cross-sectors in actively participating in encouraging people to behave in a healthy life. GERMAS is a movement initiated by the President of the Republic of Indonesia that prioritizes promotive and preventive efforts without compromising curative and rehabilitative efforts carried out jointly by all components of the nation with awareness, willingness, and ability to behave in a healthy manner to improve the quality of life [3].

The implementation and implementation of GERMAS must start from the family, because the family is the smallest part of society that forms personality. the theme of Indonesia Loves Healthy with the sub-theme of Healthy Living Society, Strong Indonesia. This theme must be interpreted broadly, in line with the Healthy Indonesia Program with a family approach through the Healthy Living Community Movement (GERMAS). In particular, GERMAS is expected to increase community participation and participation for healthy living, increase community productivity, and reduce the burden of health costs. At the initial stage, GERMAS nationally began by focusing on three activities, namely doing 30 minutes of physical activity per day, eating fruits and vegetables, and having regular health checks. These three activities can be started by yourself and your family, done right now, and do not require a large amount of money [2]. 
Regarding the current situation, namely the Covid-19 pandemic which first occurred in Indonesia on March 2, 2020. As of year 2020 to 2021, the development of positive cases of Covid-19 in Indonesia has reached 719,219 cases with 589,978 people declared cured and 21,452 people died (Nuryanti, 2020). In September 2020, four regions in Greater Jakarta were confirmed to be in the Covid-19 red zone. The four areas are Bogor City, Depok City, Bekasi City, and Bekasi Regency. So that the extension of the Large-Scale Social Restrictions (PSBB) in the Jakarta and West Java area will be continued until next October. Until December 2020, Covid-19 cases in Jabodetabek were considered to be getting worse towards the end of the year (Surjaya, 2020). In Depok City, there are currently 23,729 confirmed cases of Covid-19 with a total of 4,693 active patients on January 22, 2021 through the official Depok City website regarding Covid-19 [4].

One of the government's efforts to break the chain of spread of the Covid-19 virus is by re-echoing GERMAS to the community so that it is implemented to break the chain of virus spread. This is because in GERMAS there are healthy lifestyles that can prevent the transmission of Covid-19. One of them is to use a mask when coughing or cover your mouth with the inside of your upper arm. This lifestyle is suitable to be implemented as an effort to prevent the transmission of Covid-19. and GERMAS is also easy to do by every community, so that GERMAS is considered the most suitable guideline to be applied in people's daily lives. GERMAS is also an effort by the government to involve and empower the community in terms of maintaining, improving and protecting their health. The goal is to make people aware, willing, and able to be independent. Therefore, the purpose of this activity is also to assist the government's efforts in disseminating information about the importance of implementing GERMAS in the Covid-19 pandemic [1]. Until now, there are still many teenagers who ignore health protocols to date. Like crowding with their peers without wearing a mask. Where this can increase the risk of transmission of Covid-19 and this can lead to the emergence of clusters of Covid-19 transmission, namely family clusters. Because the teenager could have been exposed to the Covid-19 virus from his friends when they were together. This can be due to the lack of awareness of teenagers about Covid-19 and also not getting the right information about Covid-19 and how to deal with it. It is necessary to do the right information to provide education to teenagers regarding the prevention of Covid-19 transmission, such as through GERMAS [5]

University or high school youth can also be used as a medium to disseminate this information to their families who are their smallest community by social media or online education. Because these high school youth are able to understand the importance of GERMAS in handling Covid-19, they will be able to provide education to their families so that their families can implement GERMAS independently. If the family of the teenager is able to understand and implement GERMAS well, then they can also provide appropriate education to the surrounding environment or the community around the family such as neighbors or other family members[6] [5]. 
In addition, these high school youth can play a role in disseminating information on the importance of GERMAS in overcoming the transmission of Covid-19 to their other community networks such as peers or their own organizations directly or indirectly, such as the use of social media. Therefore, youth groups, especially high school students, are a suitable group to understand and receive education regarding the importance of GERMAS in overcoming the transmission of Covid-19 [7].

\section{METHODS}

\section{Solutions offered to schools}

In the community service program activities in the Implementation of the Healthy Living Community Movement during the Covid-19 period, it was carried out by online using the conference method, namely by providing information to participants, where those present can participate actively.

\section{Problem Solving Method}

The approaches offered to solve the problems that exist in several high schools in Bekasi and Depok that have been agreed upon are:

a. Provide information related to the Healthy Living Community Movement, starting from the understanding, benefits of implementing and the impact of not doing so.

b. Providing information on how to deal with Covid-19 by implementing the Healthy Living Community Movement.

\section{Problem Solving Stages}

Stages of Problem Solving that should be applied by participants from several high schools in Bekasi and Depok is an increase in knowledge related to how to live a healthy lifestyle and participate in implementing a healthy lifestyle in everyday life., for this case in Budi Cendekia Islamic School.

\section{RESULT AND DISCUSSION}

The implementation of this community service was carried out on February, 2021. This activity was carried out with zoom meeting and follow up a week after the event, with team coordination to school members and students directed by Ms. Erlina, a public health lecturer at Esa Unggul University who was able to support the success of the activity. The number of participants and the community service team who attended were 81 people from the initial target of 50 participants. Participants were very enthusiastic in participating in the healthcare events and socialization. The parties involved are representatives of SMA Budi Cendekia Islamic School and 2 lecturers from the Faculty of Health Sciences and Faculty of Business Economics the Esa Unggul University. 
Community service in this activity uses an approach method developed as follows:

1. Preparation phases the activity begins with the community service implementing team asking permission from the school. This activity discusses the implementation of activities which include implementation time, participants and the tools needed. The school representative teacher conveys the plan for this service activity to the students to take part in the activity.

2. Implementation Stage The next stage is conditioning participants, namely class representatives. In this community service activity, general information is provided, including:

a) Definition of GERMAS

- The relationship of GERMAS with conditions in the last 30 years.

- Factors causing disease.

- Performance indicators.

- The parties involved.

- Benefits of GERMAS

b). Physical activity: Disease prevention through community movement.

\begin{tabular}{lcc}
\hline Variables & $\begin{array}{c}\text { Value Category } \\
\text { Prosentage } \\
(\%)\end{array}$ & 0 \\
& 1 & 0 \\
Event punctuality & 2 & $1(2,0)$ \\
& 3 & $21(42,9)$ \\
& 4 & $27(55,1)$ \\
Theme suitability & 5 & 0 \\
& 1 & 0 \\
Easy to understand material & 2 & $2(4,1)$ \\
& 3 & $11(22,4)$ \\
& 4 & $36(73,5)$ \\
\hline & 5 & 0 \\
Useful activities & 1 & 0 \\
& 2 & $3(6,1)$ \\
& 3 & $21(42,9)$ \\
& 4 & $25(51)$ \\
& 5 & 0 \\
& 1 & 0 \\
& 2 & $2(4,1)$ \\
& 3 & $10(20,4)$ \\
& 4 & $37(75,5)$ \\
\hline & 5 & 0 \\
& 1 & 0 \\
& 2 & $25(51)$ \\
\hline
\end{tabular}

Fig. 1. Participants' assessment related to community service events. 
The results of the research on the distribution of respondents on a number of their characteristics are shown in Figure 1 participants assessment related to community service events, that presented results as above:

a. the variable timeliness of the event mostly answered very well at $55.1 \%$.

b. the variable according to the theme mostly answered very well at $73.5 \%$.

c. the material variables are easy to understand, most of them answered very well at $51 \%$.

d. the most useful activity variables answered very well at $75.5 \%$.

e. the value of the overall activity variable mostly answered very well at $51 \%$.

The method chosen is the seminar method that can be assisted by using teaching aids to clarify the descriptions presented to participants. This seminar method is often used in the learning process in schools starts from the low level to the college level, especially during the current Covid-19 pandemic. Respondents in this study were students and high school students. This results it can be concluded that the community service program was successful, because the value of each variable is above $51 \%$, and based on the percentage data results, it shows that community service carried out by public health students will affect the target in carrying out GERMAS care.

\section{CONCLUSION}

In GERMAS especially related to the Healthy Living Community Movement there are healthy lifestyles that can prevent the transmission of Covid-19. One of them is to use a mask when coughing or cover your mouth with the inside of your upper arms. This lifestyle is suitable to be implemented as an effort to prevent the transmission of Covid-19. The goal is to make people aware, willing, and able to be independent. Therefore, the purpose of this activity is also to assist the government's efforts in disseminating information about the importance of implementing GERMAS in the Covid-19 pandemic. The implementation of this community service provides information related to the Healthy Living Community Movement, so that there is an increase in knowledge related to how to live a healthy lifestyle and participate in implementing a healthy lifestyle in everyday life. By using the Seminar Method, it can be used as a teaching aid to clarify the descriptions presented to participants. Respondents in this study were students and high school students. The results of the implementation of community service activities are obtained, as follows:

1. The variable of timeliness of the event mostly answered very well at $55.1 \%$.

2. The theme suitability variable mostly answered very well at $73.5 \%$.

3. The material variables are easy to understand, most of them answered very well at $51 \%$.

4. The most useful activity variables answered very well at $75.5 \%$. 
5. The overall value variable for most of the activities answered very well at $51 \%$.

So it can be concluded that the community service event that has been carried out has been successful, with the results of each variable being more than $51 \%$. So that this community service will affect the target in carrying out the maintenance and implementation of GERMAS in daily life. As for suggestions in implementing this community service activity, namely increasing the series of events to be better in the future, for presenters in providing material and answering participant questions, it is hoped that it will be further improved and use language that is easy to understand in layman's language and is not complicated, so that participants can better understand core of the material of the healthy living movement. And the need to increase two-way communication activities with schools after the pandemic so that the contributions of the committees during the event can be monitored and implemented in the field properly. Especially for students at Budi Cendekia Islamic School.

\section{ACKNOWLEDGMENTS}

The author would like to thank all the teachers, members, and students of Budi Cendekia Islamic School, Depok City West Java, Indonesia who have supported this community service activity, to the committee team, and to the principal for the valuable advice.

\section{REFERENCES}

[1] World Health Organization, "Noncommunicable Diseases Country Profiles 2018," World Health Organization, 2018. .

[2] Ministry of Health of the Republic of Indonesia, "Indonesia Basic Health Research, 2018,, 2018.

[3] F. Di Gennaro et al., "Coronavirus diseases (COVID-19) current status and future perspectives: A narrative review," International Journal of Environmental Research and Public Health. 2020, doi: 10.3390/ijerph17082690.

[4] R. Agustina et al., "Universal health coverage in Indonesia: concept, progress, and challenges," The Lancet. 2019, doi: 10.1016/S0140-6736(18)31647-7.

[5] R. Khana, M. M. Singh, F. Damanhoori, and N. Mustaffa, "Investigating the importance of implementing ethical value on a healthcare system within a social media context," Int. J. Innov. Creat. Chang., vol. 12, no. 5, 2020.

[6] G. Gozali, B. J. Kusuma, M. Mahfud, A. A. Soeparlan, and M. Huda, "Membangun Jiwa Entrepreunership Santri dan Santriwati Pondok Pesantren Al Mujahidin Balikpapan," J. Abdimas Mahakam, 2019, doi: 10.24903/jam.v3i1.406.

[7] BPJS, “BPJS Kesehatan,” Badan Penyelenggara Jaminan Sosial, 2017. . 